\title{
Pemanfaatan Aplikasi Web Sebagai Salah Satu Solusi Media Pembelajaran Jarak Jauh Di Masa Pandemi Covid-19
}

\section{Eri Teguh Kurniawan Suyatna}

\author{
SMP Negeri 1 Ciasem \\ eridesign4animagination@gmail.com
}

\section{Article History \\ accepted 01/12/2020}

published 01/03/2021

\begin{abstract}
This research is attempted to prove that Web-Application (Web App PJJ) utilization is one of distance learning solutions during Covid 19 Pandemic. This reaserach aimed at (1) knowing how this new Web App PJJ is easy, light, and complete learning solution but still interesting and communicative between teachers and students, parents (2) finding out the effectiveness and efficiency of using the Web App PJJ with Google Apps Script to facilitate and improve the science learning process especially during the Covid-19 pandemic that almost all process of learning and teaching held remotely. It is conducted by applying classroom research to grade 8 and 9 students of state junior high school, SMP Negeri 1 Ciasem Subang Jawa Barat. This research was instigated by the questionnaires result that $85 \%$ students supposed this Web App PJJ is very easy and practical to be used in facilitating teaching learning process without installing application or spending much data package and depending on internet connection. From the navigation and the menu provided by the application, $82 \%$ of the students stated that they have no trouble moving from one menu to another, easy to see learning outcomes and assignments' reports. In the result of 100 students for knowing students response to the excellence of this application, the result was $85 \%$ which showing that the media was on very good and proper category to be used
\end{abstract}

Keywords: Distance Learning, Web Application

\begin{abstract}
Abstrak
Penelitian ini mencoba untuk membuktikan bahwa pemanfaatan Web-Application (Web App PJJ) merupakan salah satu solusi pembelajaran jarak jauh selama Pandemi Covid 19. Penelitian ini bertujuan untuk (1) mengetahui bagaimana Web App baru PJJ ini menjadi solusi pembelajaran yang mudah, ringan, dan lengkap namun tetap menarik dan komunikatif antara guru dan siswa, orang tua (2) mengetahui efektivitas dan efisiensi penggunaan Web App PJJ dengan Google Apps Script untuk memfasilitasi dan meningkatkan proses pembelajaran sains terutama pada masa pandemi Covid-19 yang hampir semua proses belajar mengajar berlangsung dari jarak jauh. Penelitian dilakukan dengan mengaplikasikan penelitian kelas pada siswa kelas 8 dan 9 SMP Negeri 1 Ciasem Subang Jawa Barat. Penelitian ini dilatarbelakangi oleh hasil angket bahwa 85\% siswa berpendapat bahwa Aplikasi Web PJJ ini sangat mudah dan praktis digunakan dalam memfasilitasi proses belajar mengajar tanpa perlu menginstal aplikasi atau menghabiskan banyak paket data dan bergantung pada koneksi internet. Dari navigasi dan menu yang disediakan aplikasi, $82 \%$ siswa menyatakan tidak mengalami kesulitan berpindah dari satu menu ke menu lainnya, mudah melihat hasil belajar dan laporan tugas. Dari hasil 100 siswa mengetahui respon siswa terhadap keunggulan aplikasi ini diperoleh hasil $85 \%$ yang menunjukkan bahwa media berada pada kategori sangat baik dan layak untuk digunakan.
\end{abstract}

Kata kunci: pendidikan jarak jauh, aplikasi web

Social, Humanities, and Education Studies (SHEs): Conference Series https://jurnal.uns.ac.id/shes 


\section{PENDAHULUAN}

Saat ini kita sedang mengalami pandemi Covid-19 yang ditetapkan oleh WHO sejak bulan Maret 2020. Karena rumitnya penangan wabah ini membuat pemerintah mengeluarkan keputusan "Physical Distancing" atau "Social Distancing" dengan tujuan untuk memutus rantai penyebaran virus ini. Sehingga dampak dari keputusan tersebut begitu terasa pada sektor ekonomi, pariwisata, kesehatan, dan sektor lainnya.

Dunia pendidikan pun tak luput menjadi bagian terdampak dari kebijakan ini akibat keputusan pemerintah yang lebih mengutamakan kesehatan dan keselamatan peserta didik. Banyak pemangku kebijakan sekolah yang tidak siap melaksanakan pembelajaran daring atau luring. Peralihan cara belajar ini memaksa banyak pihak untuk lebih kreatif dalam membuat proses pembelajaran jarak jauh lebih mudah dan menyenangkan.

Penggunaan Teknologi dalam proses pembelajaran bukan tidak dengan masalah, mulai dari penguasaan terhadap ICT yang masih rendah, keterbatasan sarana dan prasarana di lingkungan sekolah, jaringan internet yang belum menjangkau luas hingga ke pelosok daerah dan biaya yang cukup besar untuk melaksanakan pembelajaran jarak jauh via daring.

Berbagai usaha telah dilakukan oleh pemerintah Indonesia untuk meminimalisir masalah ini seperti membuat kurikulum darurat, penyediaan portal belajar gratis, pemberian kuota gratis untuk Dosen, Guru dan Siswa, tatap muka pada zona hijau dengan tetap memperhatikan protokol kesehatan. Sementara untuk daerah dengan kategori zona kuning atau merah tetap melaksanakan pembelajaran jarak jauh (PJJ).

Salah satu strategi yang sering digunakan Guru/Dosen untuk Pembelajaran Jarak Jauh yakni dengan membuat kelas virtual seperti Whatsapp Group, Telegram Group, Google Classroom atau Microsoft Teams. Kelas virtual ini dikelola oleh guru atau tim yang didalamnya terdapat siswa. Saat guru atau dosen akan memberikan sebuah materi pembelajaran seperti artikel, video, quiz, atau video confrence maka akan disematkan link dalam sebuah postingan dalam kelas virtual tersebut. Tentunya akan banyak sekali link yang harus dibuka oleh siswa sehingga tidak lagi menjadi efektif bila setiap topik terdapat banyak link yang harus dikelola oleh guru atau siswa. Belum lagi penggunaan kuota internet yang cukup besar karena siswa dan guru harus menginstal aplikasi tersebut.

Berdasarkan masalah yang muncul di atas, penulis membuat Aplikasi Web PJJ yang ringkas, ringan, lengkap sehingga untuk sebuah skenario pembelajaran terdapat materi, video, link video confrence, penugasan, quiz, sticky notes dan rekap laporan kepada orang tua yang terdapat dalam satu laman saja namun tujuan pembelajaran tetap tercapai serta bisa memfasilitasi peserta didik yang tidak memiliki smartphone.

Sebagai antisipasi pencegahan penularan virus Covid-19, maka pemerintah telah mengeluarkan kebijakan seperti social and physical distancing hingga pembatasan sosial berskala besar (PSBB). Kondisi ini mengharuskan Guru/Dosen untuk tetap mengajar dari rumah (WFH) sedangkan untuk peserta didik dan mahasiswa belajar dari rumah (BDR).

Kondisi demikian tentu saja membuat lembaga pendidikan harus siap dengan segala skenario pembelajaran dan menuntut untuk melakukan inovasi dalam proses pembelajaran. Salah satu bentuk skenario tersebut ialah dengan melakukan pembelajaran secara online atau daring (dalam jaringan) dan pembelajaran diluar jaringan atau luring. Akan tetapi, dalam pembelajaran online ini tidak terlepas dari permasalahan yang menjadi kendala dalam pelaksanaannya. Oleh karena itu diperlukan solusi dan juga langkah taktis yang diambil oleh guru/dosen sebagai fasilitator dalam pembelajaran jarak jauh.

Berdasarkan kajian sebelumnya oleh M. Hadi Nur (2020) yang mengkaji tentang Pembelajaran daring di era pandemi. Beliau mengemukakan bahwa pembelajaran daring ini menimbulkan banyak masalah bagi pendidik dan peserta didik seperti pembelajaran yang tidak terpenuhi oleh pendidik dan akhirnya diberikan kepada siswa 
tugas tambahan. Selain itu penugasan kepada peserta didik menjadi lebih banyak, dan akhirnya jadi sebuah masalah baru, sistem informasi yang menjadi penghambat karena sinyal yang kurang memadai. Sehingga akhirnya pembelajaran daring tersebut dirasa tidak efekif.

Hambatan atau kendala saat pembelajaran daring merupakan aspek penting yang harus dikaji secara mendalam serta dicari jalan keluarnya. Menurut Suryani (2010) bahwa Adanya hambatan pada proses pembelajaran dapat menurunkan minat belajar mahasiswa. Seperti yang dilaporkan oleh Pangondian et all, (2019) yang menyatakan bahwa faktor-faktor yang menjadi kunci kesuksesan pembelajaran daring adalah ketersediaan sarana dan prasarana. Berdasarkan penelitian tersebut, kajian mengenai inovasi dalam sistem pembelajaran daring untuk mata pelajaran IPA agar ketercapaian dalam penugasan belum pernah dilakukan. Penulis mencoba membuat media aplikasi web untuk penugasan yang sudah dilengkapi dengan materi, games sederhana, video, link vicon, quiz, sticty notes dan rekap laporan kepada orang tua.

\section{HASIL DAN PEMBAHASAN}

Hasil dari pengalaman selama menggunakan kelas maya seperti google classroom ini menghasilkan ide untuk membuat aplikasi yang lebih sederhana namun memudahkan guru untuk memberi materi, video youtube, link vicon, link quiz penugasan, sticky notes, rekap laporan kepada orang tua hanya dengan Apps Script. Guru hanya menuliskan ringkasan materi, insert gambar, embed video youtube, link vicon, link quiz pada spreadsheet online (Google Sheets). Outputnya berupa tampilan website yang bisa diakses kapan saja, dimana saja, aman dan mudah untuk digunakan.

Secara umum, langkah untuk membuat Web App PJJ ini seperti yang digambarkan di bawah ini:

1. Membuat akun pada Google Drive

Langkah paling awal untuk menikmati layanan Platform Google Cloud adalah mendaftar secara gratis pada gmail.com. Setelah terdaftar, maka kita akan membuat akun pada Google Drive dengan alamat domain gmail. Perlu diketahui bahwa akun gmail adalah versi gratis dan memiliki limit kuota. Secara detail paparan mengenai ini dengan mengklik tautan $<$ quota $>$

2. Membuat Template

Setelah membuat akun Gmail dan Gdrive, maka kita akan membuat ringkasan materi, embed video youtube, pertanyaan penugasan bahkan games sederhana hanya pada spreadsheet online yang disebut Google Sheet. Seperti yang dijelaskan sebelumnya. Google Sheet ini sama seperti aplikasi Excel yang bersifat offline yang memiliki baris (row) dan kolom (column). Pertemuan antara baris dengan kolom disebut dengan cell. Perlu diketahui sebelumnya bahwa setiap file Google Sheet (Spreadsheet) memiliki ID yang unik pada URL. Jika tak ingin repot saat membuat salinan template, maka menggunakan metode SpreadsheetApp.getActiveSpreadsheet();

3. Menuliskan kode pada Google Apps Script

Seperti yang telah dijelaskan sebelumnya, untuk membuat program web aplikasi pada google, disediakan kode editor yang bisa diakses dari Menu Google Sheet seperti terlihat pada gambar disamping atau terpisah dari aplikasi Google Sheet, Doc, Slide seperti pada gambar diatas. Disini penulis membuat web aplikasi dengan tipe bounding atau menyatu dengan aplikasi google

Setelah membuka kode editor, maka kita bisa mulai menulis kode Google Apps Script disini. Merujuk pada halaman https://developers.google.com/appsscript/guides/web bahwa untuk membuat web app pada layanan google diperlukan dua persyaratan yang harus dimiliki dalam menulis kode dengan apps script yaitu:

a. Fungsi doGet/doPost

b. Fungsi return HTML service, HtmlOutput object atau Content service TextOutput object. 
Bahasa HTML digunakan untuk membuat struktur content pada sebuah web page (teks, image, forms dll). Untuk menggunakannya kita menggunakan HTML tags. Sedangkan untuk mempercantik halaman quiz, diperlukan bahasa Cascade Style Sheets (CSS). Jadi CSS digunakan untuk membuat "make-up" konten pada sebuah web page agar terlihat indah dan menarik seperti mengubah warna, font, posisi, ukuran dan lain-lain. Hingga penulis menyusun naskah ini, bahasa yang digunakan adalah yang terbaru yaitu HTML5 dan CSS3.

Javascript merupakan bahasa komputer atau kode pemrograman yang digunakan pada website agar website tersebut menjadi lebih interaktif dan dinamis. Javascript adalah jenis bahasa pemrograman yang bekerja pada sisi client. Penggunaan kode javascript pada sebuah website bersifat opsional, artinya tidak harus selalu ada. Penulis belajar bahasa HTML, CSS dan Javascript secara otodidak dari website https://www.w3schools.com/

Agar code apps script bisa membaca template soal pada google sheet maka harus diketahui hierarchy dari sebuah spreadsheet, yakni alamat URL/ID, lalu pada sheet yang dituju dan cell atau range yang digunakan.

Google Apps Script bekerja untuk melayani service sesama Platform Google atau dengan layanan service yang berasal dari luar (external service). Dalam kasus ini, melayani request dari web app yang dibuat dengan HTML dan CSS. Agar web app bisa berkomunikasi (menulis response) pada spreadsheet dengan apps script maka javascript yang terdapat pada web app membuat perintah khusus dengan menjalankan:

4. Deploy as Web App

Saat pertama kali web aplikasi yang dibuat dengan Apps Script ingin dieksekusi (run), maka Google sangat memperhatikan keamanan web. Sehingga harus ada izin walaupun yang membuat adalah penulis sendiri seperti pada gambar.

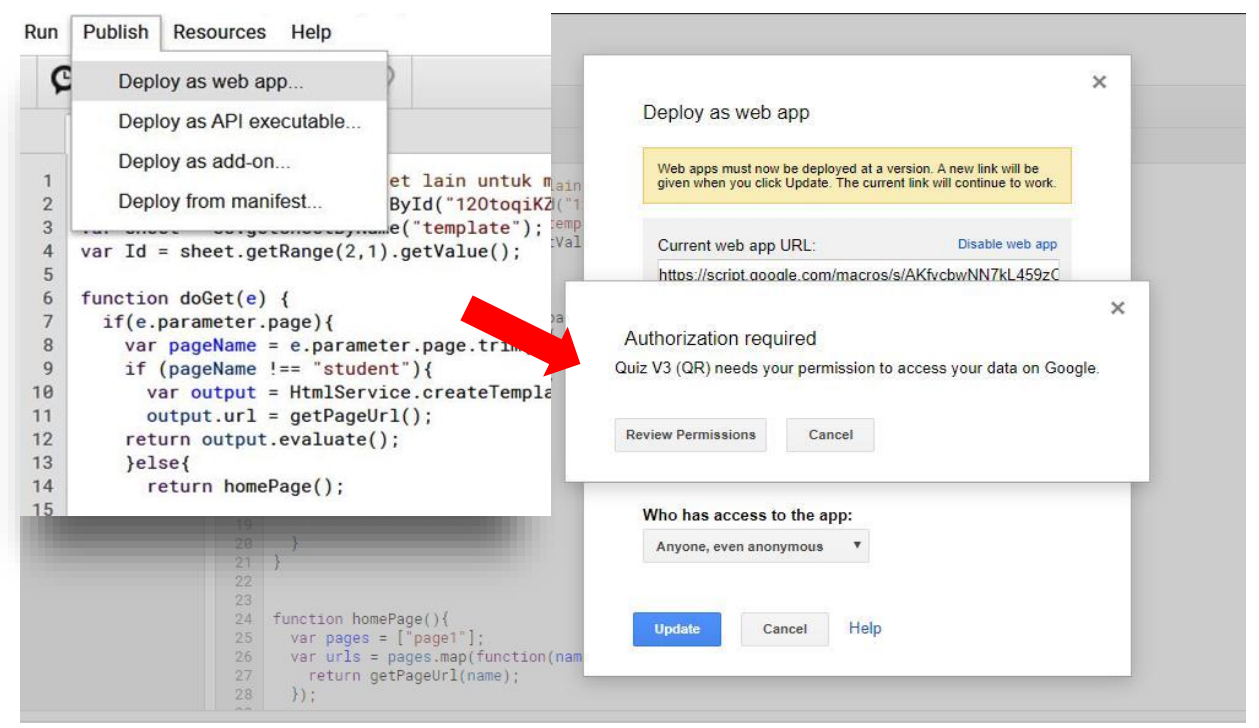

Setelah melewati tahapan perizinan dan tidak ditemukan error pada code maka web aplikasi Web App PJJ siap diuji coba.

5. Membagikan Link Web App melalui Whatsapp Group atau Google Classroom

Setelah tahap 4 yakni Deploy As Web App, maka didapatkanlah sebuah link URL yang panjang. Untuk mempermudah siswa dalam mengakses, maka gunakan bantuan web penyedia Shortener Link seperti https://bitly.com kemudian mempostingnya pada whatsapp group/google classroom 
Pada web app versi pertama, penulis membuat halaman web app PJJ yang dapat dibuka dengan browser. Namun saat diuji coba, tampilan web app belum responsive. Menurut laman w3schools, responsive adalah bagaimana membuat web page secara otomatis dapat menyesuaikan dengan berbagai ukuran perangkat (desktop, tablet atau smartphone) namun tetap terlihat bagus.

Responsive Web Design is about using HTML and CSS to automatically resize, hide, shrink, or enlarge, a website, to make it look good on all devices (desktops, tablets, and phones). Web pages can be viewed using many different devices: desktops, tablets, and phones. Your web page should look good, and be easy to use, regardless of the device

Untuk versi awal yang menggunakan desktop masih dapat digunakan, namun untuk versi mobile, form identitas sudah terlihat tidak responsive terhadap ukuran smart phone sehingga harus tampil dengan orientasi landscape. Padahal tujuan awal pembuatan Web App PJJ ini untuk meminimalisir penggunaan PC Desktop sehingga siswa bisa menggunakan smartphone masing-masing. Perubahan ini dibuat dengan asumsi bahwa lebar layar dibagi menjadi 12 kolom, lalu membuat class pada element HTML. Sehingga kita bisa mengatur breakpoint untuk tampilan berbagai perangkat. Pada file CSS diatur sebagai berikut :

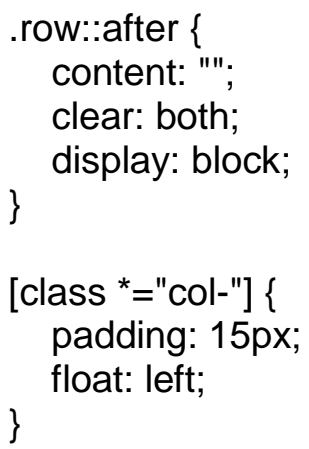

Untuk Mobile Screen :

[class* $="$ col-"] \{

width: $100 \%$;

@media only screen and (min-width:

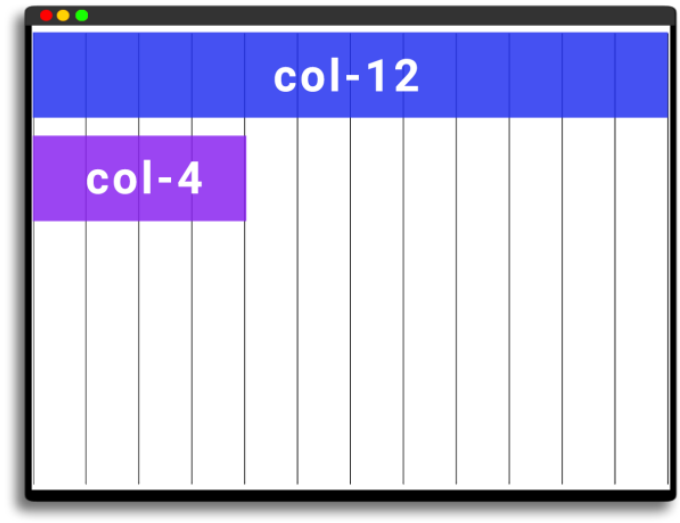

600px) \{

/* For tablets: */

.col-s-1 \{width: $8.33 \%$;

.col-s-2 \{width: $16.66 \%$;

.col-s-3 \{width: $25 \%$;

.col-s-4 \{width: $33.33 \%$;

.col-s-5 \{width: $41.66 \%$;

.col-s-6 \{width: $50 \%$;

.col-s-7 \{width: $58.33 \%$;

.col-s-8 \{width: $66.66 \%$;

.col-s-9 \{width: 75\%;

.col-s-10 \{width: 83.33\%;

.col-s-11 \{width: $91.66 \%$;

\}

.col-s-12 \{width: $100 \%$;

@media only screen and (min-width: 768px) \{

/* For tablets: */ 
.col-1 \{width: $8.33 \%$;

.col-2 \{width: $16.66 \%$;

.col-3 \{width: $25 \%$;

.col-4 \{width: $33.33 \%$;

.col-5 \{width: $41.66 \%$;

.col-6 $\{$ width: $50 \%$; $\}$

.col-7 \{width: $58.33 \%$;

.col-8 $\{$ width: $66.66 \% ;\}$

.col-9 \{width: 75\%;

.col-10 \{width: $83.33 \%$;

.col-11 \{width: $91.66 \%$;

\}

.col-12 \{width: $100 \%$;
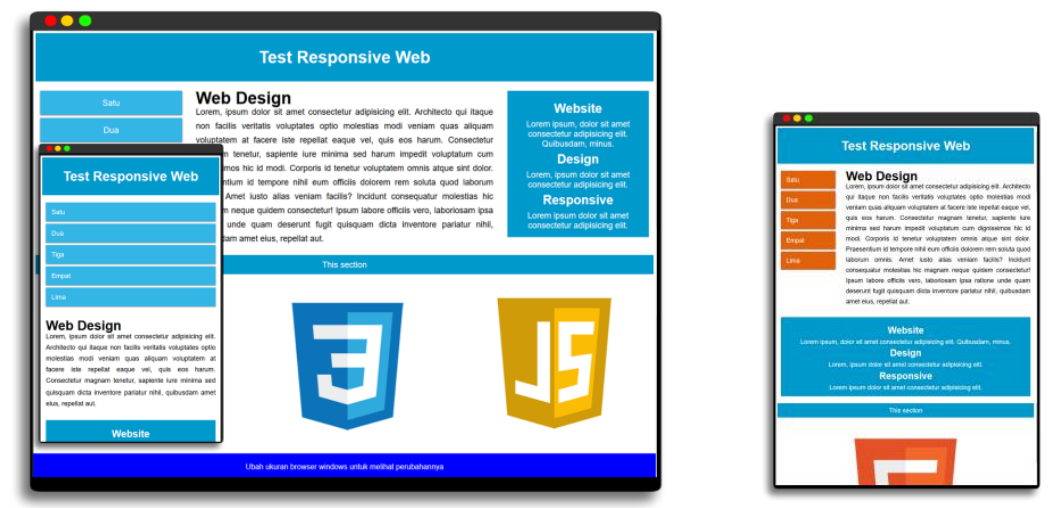

Setelah berhasil membuat responsive web app, kemudian penulis menambahkan sticky notes dan

menambahkan rekap laporan kelengkapan tugas kepada orang tua.

Pada versi 2 sudah ditambahkan catatan kecil yang diambil dari kolom kesimpulan pembelajaran materi dan dilengkapi dengan nama siswa asal kelas dan penilaian kualitatif dari guru. Tujuannya adalah siswa bisa melihat hasil penilaian kualitatif tersebut dan orang tua bisa melihat sejauh mana anaknya bisa memahami pembelajaran saat itu. Dan tidak kalah pentingnya, rekap hasil yang dibuat dalam tabel spreadsheet akan dibaca menjadi sebuah tabel HTML yang dapat diakses oleh orang tua dan siswa. Sehingga orang tua bisa membantu guru untuk memantau penugasan yang sudah dikerjakan.

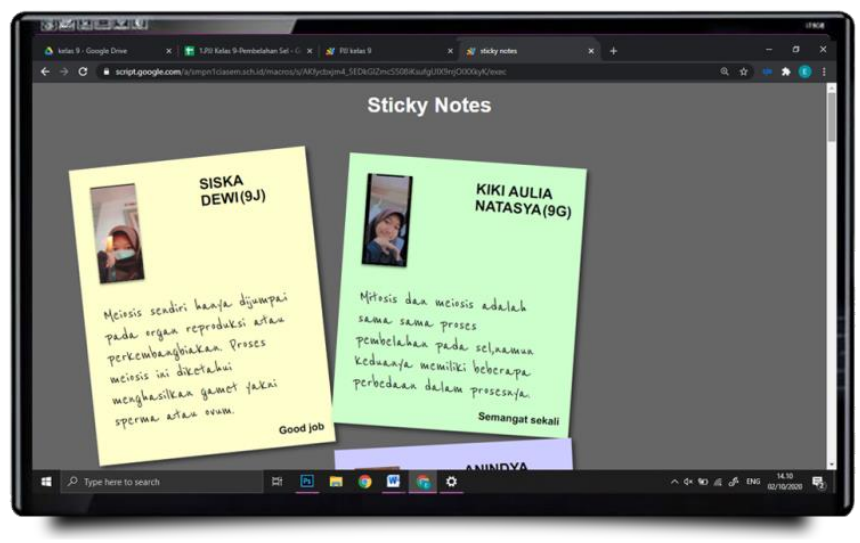




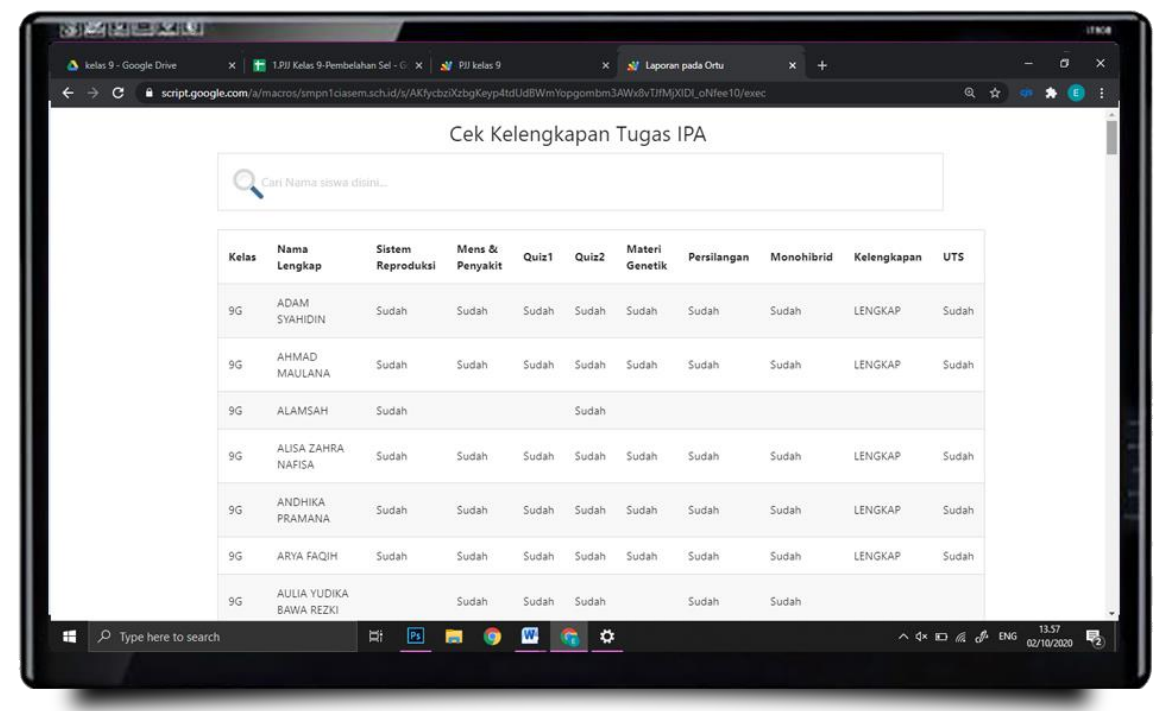

Pada bagian ini akan diuraikan dan dianalisis hasil penelitian di lapangan selama penugasan kompetensi dasar (KD) 3.1 pada kelas 8H, 8I, 9G, 9H, 9I, 9J. Hasil penugasan pada kelas 8 yakni sebanyak 4 penugasan yang terbagi menjadi Tugas 1 Gerak Manusia (otot), Tugas 2 Gerak Manusia (rangka/tulang), Tugas 3 Gerak Hewan, Tugas 4 Gerak Tumbuhan. Sementara pada kelas 9 terdapat 2 penugasan pada KD tersebut yakni Tugas 1 Sistem Reproduksi, Tugas 2 siklus menstruasi dan penyakit. Hasil yang didapatkan adalah sebanyak $95,38 \%$ penugasan selesai dikerjakan oleh siswa kelas 8 dari 65 siswa yang memiliki smartphone. Sementara untuk kelas 9, diperoleh prosentase $86,50 \%$ dari 137 siswa yang memiliki smartphone.

Metode yang digunakan oleh peneliti yaitu membuat query dengan kategori lengkap pada sheet rekap penugasan yang akan dijadikan HTML Table. Saat akan dilaksanakan Quiz atau ulangan harian. Daftar nama siswa dengan kategori "LENGKAP" akan muncul pada pilihan dependent dropdwon. Sehingga seminggu sebelum quiz, penulis sudah mengumumkan pada group WA untuk segera melengkapi tugas yang belum dikerjakan. Agar mempermudah siswa yang tertinggal informasi di group WA karena keterbatasan kuota, maka penulis membuat rangkuman link dari tugas pertama hingga terakhir. Sehingga siswa yang tidak masuk dalam Google Classroom akan tetap mendapatkan informasi mengenai penugasan ini.

Sheet Rekap ini akan dibagikan dalam bentuk link HTML Table kepada walikelas, siswa dan orang tua. Sehingga terjadi bentuk sinergis antara guru, siswa dan orang tua dalam memantau penugasan IPA khususnya KD 3.1. Pada halaman Laporan Ortu berupa tampilan HTML Table penugasan IPA yang bisa dilihat oleh orang tua dan siswa, memberikan sumbangsih positif kepada penulis. Tentu saja atas sikap kerjasama yang baik antara semua pihak. Halaman ini bisa diakses melalui menu Web App PJJ dimana saat dibuka akan menunjukan penugasan awal hingga terakhir. Pada bagian bawah disediakan tombol chat Whatsapp jika siswa atau orang tua ingin bertanya kepada guru. 
Tabel 1. Hasil Dari Kuesioner Tentang Uji Praktikalitas Aplikasi Web App

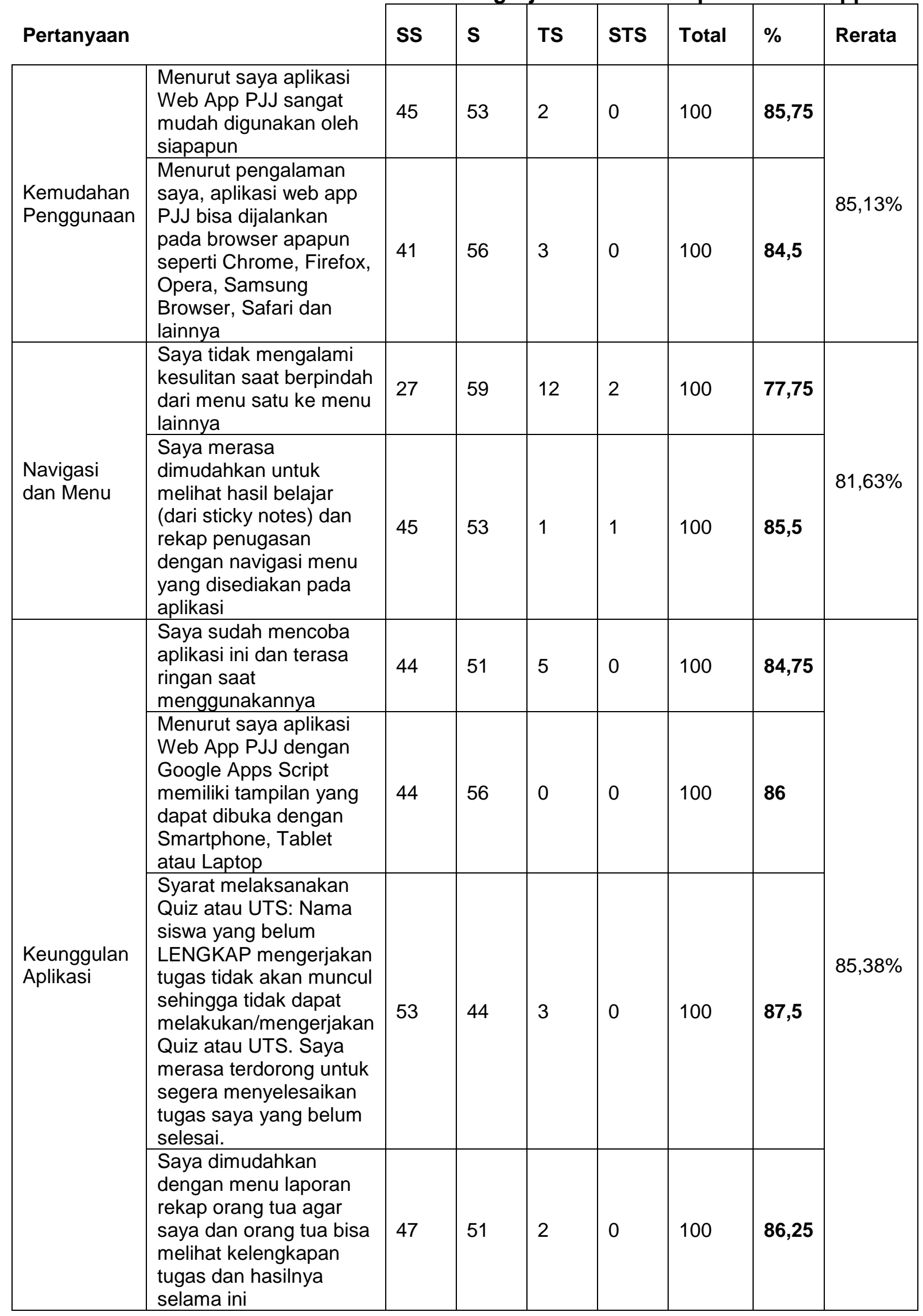




\begin{tabular}{l} 
Menurut saya Aplikasi \\
ini lengkap, ringan, da \\
memudahkan karena \\
tidak direpotkan dengan \\
banyak link (materi, \\
video, quiz, video \\
conference) dalam satu \\
pertemuan. \\
\hline Saya bisa membaca \\
kembali hasil/progres \\
pembelajaran dari sticky \\
notes yang dibuat oleh \\
sistem secara otomatis \\
nurut Sugiono (2016) \\
Sng mengkategorikan \\
Sangat kurang. Ada \\
Sangat kurang \\
Kurang \\
Cukup \\
Kuat \\
Sangat Kuat
\end{tabular}

Dari data pengolahan di tabel tersebut diperoleh kesimpulan bahwa responden menilai sangat baik pada kategori pertanyaan Kemudahan Aplikasi. Penilaian ini didapatkan dari rerata kategori pertanyaan yakni sebesar $85,13 \%$. Sementara untuk kategori Navigasi dan menu, prosentase yang diperoleh adalah $81,63 \%$ (sangat baik) dan $85,38 \%$ untuk kategori pertanyaan mengenai keunggulan aplikasi.

\section{SIMPULAN}

Responden menilai bahwa aplikasi ini bisa memudahkan dalam pembelajaran IPA di masa pandemi covid-19. Selain itu responden siswa merasa termotivasi untuk penyelesaian tugas dengan sistem rekap query dengan kategori lengkap. Selebihnya adalah pujian terhadap aplikasi dan harapan terhadap pengembangan aplikasi selanjutnya. Secara umum dapat disimpulkan bahwa Aplikasi Web App PJJ ini memudahkan siswa dalam pembelajaran di masa pandemi karena aplikasi ini sudah dilengkapi dengan ringkasan materi, video, penugasan, laporan ortu dan sticky notes.

\section{DAFTAR PUSTAKA}

Budiyono. 2011. Penilaian Hasil Belajar. Surakarta: UNS Press

Permendikbud No. 23 Tahun 2011

Stiggins, R \& Chapuis,J. 2006. What a difference a word makes: Assessment for learning rather than assessment of learning. Diambil dari http://www.nsdc.org/library/publication/jsd.

Miller, et al. (2013). Measurement and assessment in teaching 11th edition. USA. Pearson

Clark, lan. (2011). Formative assessment and motivation: Theories and themes. Prime Research on Education, 1 (2), 027-036.

Munir. 2017. Pembelajaran Digital. Bandung: Alfabeta.

Sugiyono. (2015). Metode Penelitian Pendidikan Pendekatan Kuantitatif, Kualitatif dan RnD. Bandung: Alfabeta. 
Wuryanta, Eka Wenats. 2017. "Digitalisasi Masyarakat: Memiliki Kekuatan dan Kelemahan Dinamika Era Informasi Digital dan Masyarakat Informasi." Jurnal IImu Komunikasi 131-142.

Wahyu Yudi (2018). https://cloudhostingindonesia.com/mengenal-apa-google-cloudplatform/

https://developers.google.com/apps-script/overview

Sunarto \& Agung Hartono. 2008. Perkembangan Peserta Didik. Jakarta: Rineka Cipta. 